Посаднєва О.М. кандидат економічних наук, доцент Херсонський національний технічний університет ORCID: https://orcid.org/0000-0001-8721-5124

\title{
МАКРОЕКОНОМІЧНЕ СТРЕС-ТЕСТУВАННЯ БАНКІВ ЯК ІНСТРУМЕНТ ЗАБЕЗПЕЧЕННЯ СТІЙКОСТІ БАНКІВСЬКОЇ СИСТЕМИ
}

У статті розглянуто передумови запровадження обов'язкового макроекономічного стрес-тестування вітчизняної банківської системи. Наведено основні макроекономічні ризики, які можуть вплинути на стійкість вітчизняної банківської сфери. Виділено деякі фактори ризику діяльності банківської установи на мікрорівні, щчо впливають на ї̈ результативність. Показано вплив стрес-факторів із реального та фінансового секторів економіки на діяльність окремих банків та банківської системи у иілому. Наведено порядок здійснення стрестестування Національним банком Украӥни та охарактеризовано всі його етапи. Досліджено методику проведення стрес-тестування Національним банком Украӥни. Виділено два банки з державною часткою власності, які показали найгірші результати під час стрес-тестування. Порівняно результати стрес-тестування ПАТ «Державний ощадний банк Украӥни» та реальні результати його діяльності за аналогічні періоди. Зроблено висновки щзодо інтерпретації результатів стрес-тестування на макрорівні.

Ключові слова: банки, банківська система, стрес-тестування, макроекономічні ризики, сиенарії, стійкість.

Постановка проблеми. Остання світова фінансова криза (2008-2009 рр.), тривалий етап посткризового відновлення та значні обсяги коштів розвинених держав світу, які вимушено були спрямовані на іiі подолання, посилили актуальність розроблення ефективних методів оцінки рівня вразливості банківського сектору в умовах глобалізації фінансової системи та її впливу на макроекономічні показники кож- ної окремої країни. Світова фінансова криза виявила суттєві недоліки в оцінці та управлінні ризиками в усіх фінансових сферах. Сценарії стрес-тестування банків, які було спрогнозовано до фінансової кризи, були набагато більш оптимістичними, ніж реальні показники самої кризи, а прогнозовані втрати - значно нижчими від реальних втрат банків і держав у період кризи. 
Сьогодні методики стрес-тестування банків удосконалені і повсюдно використовуються центральними банками країн із ринковою економікою. Україна не стала винятком: Національний банк починаючи 3 2018 р. щорічно проводить стрес-тестування вітчизняних банків із метою виявлення їхніх слабких місць та їх усунення задля забезпечення безперебійної й ефективної роботи банківської системи.

Аналіз останніх досліджень і публікацій. Питаннями забезпечення стабільності на ринку банківських послуг та виявлення макроекономічних загроз розвитку банківської системи присвячено багато праць провідних і молодих вітчизняних науковців, таких як: Л. Анісімова, Ю. Бездітко, І. Данилова, П. Житній, І. Івасів, Р. Корнилюк, А. Максимова, Ж. Торяник, С. Шаповалова та ін.

Визначені науковці розглядали як вплив окремих ризиків на банківську систему в цілому, так і стрестестування на мікрорівні як елемент ризик-менеджменту, однак питання проблематики централізованого проведення стрес-тестування банків НБУ й оцінка його результатів є недостатньо дослідженими у вітчизняній науковій літературі.

Мета статті полягає у дослідженні механізмів здійснення стрес-тестування вітчизняної банківської системи Національним банком України.

Виклад основного матеріалу. Стрес-тестування банків $є$ не новим поняттям на фінансовому ринку. До фінансової кризи стрес-тестування банків здебільшого здійснювалося самими банками для управління внутрішніми ризиками. Хоча органи державного управляння деяких країн і проводили стрес-тести до фінансової кризи, як правило, припущення ризикових факторів діяльності не враховували впливу зміни еко- номічної політики на діяльність банку або враховували iii у незначному ступені.

Після фінансової кризи 2008-2009 рр. застосуванню стрес-тестування стали приділяти набагато більше уваги під час визначення державних регуляторів банківської діяльності. Центральні банки тих країн, які взяли курс на імплементацію базельських вимог, у тому числі Національний банк України, впроваджують практику стрес-тестування на регулярній основі [5]. У 2009 р. Національним банком України була прийнята Постанова «Про схвалення Методичних рекомендацій щодо порядку проведення стрес-тестування в банках України» № 460, у якій визначено основні теоретичні та методологічні засади стрес-тестування. Згідно із цією Постановою, стрес-тестування - це метод кількісної оцінки ризику, який полягає у визначенні величини неузгодженої позиції, яка наражає банк на ризик, та у визначенні шокової величини зміни зовнішнього фактора - валютного курсу, процентної ставки тощо. Поєднання цих величин дає уявлення про те, яку суму збитків чи доходів отримає банк, якщо події розвиватимуться за закладеними припущеннями [5].

Головною метою стрес-тестування є прогнозування зміни вартості певного банківського портфелю або їх загальної сукупності за заданих варіацій комплексу негативних фінансових факторів, які є змінними. Базовими факторами ризику на макроекономічному рівні $\epsilon$ такі (рис. 1).

На мікроекономічному рівні основними факторами ризику діяльності окремого банку є: можливість доступу банку до зовнішніх джерел підтримання ліквідності, конкурентна позиція банку (визначена за методикою SWOT-аналізу як узагальнена оцінка).

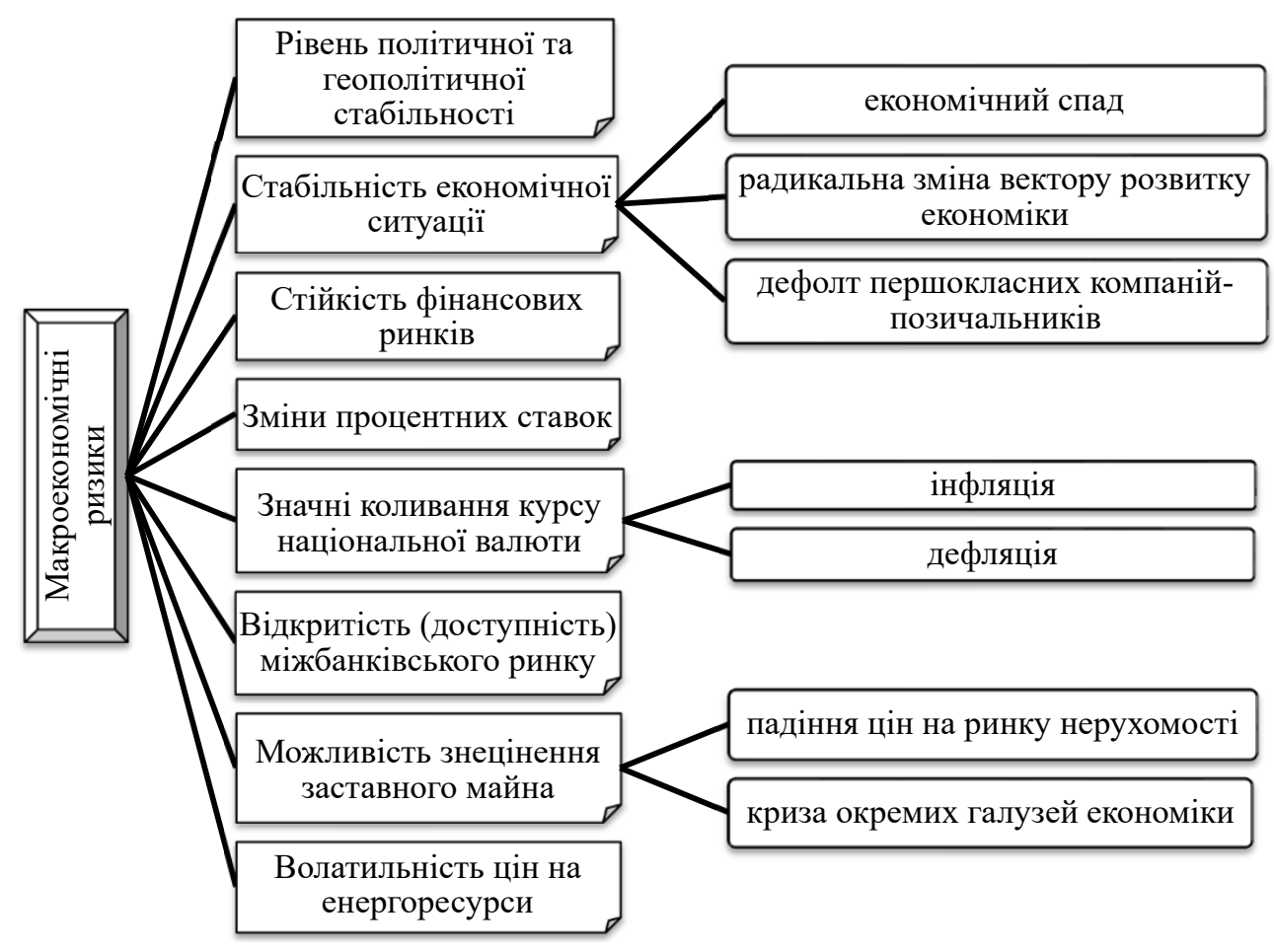

Рисунок 1 - Макроекономічні ризики банківського сектору 
Здебільшого результати стрес-тестування відображають приблизні кількісні значення впливу несприятливих подій на досліджуваний портфель банківських активів, оскільки отримати достатньо точний прогноз зміни величини банківських утрат унаслідок реалізації стресового сценарію майже неможливо. Як зазначає Метью Джонс, стрес-тестування є не стільки точним інструментом, який можна використовувати 3 науковою скрупульозністю, скільки мистецтвом, що вимагає застосування економетричних методів, експертної оцінки та серії розсудливих припущень [1].

На рис. 2 схематично зображено ланцюг поширення впливу економічних загроз та ризиків із різних джерел на економіку. Початкова загроза, що може виникнути як у реальному, так і фінансовому секторі економіки, спричинює ланцюгову реакцію, викликаючи стан загальної нестабільності в банківській системі. Іноді негативні наслідки виникають унаслідок проблем окремих юридичних осіб: компаній чи банків (одиничні загрози). У більшості інших випадків вони викликані макроекономічними дисбалансами або загальними проблемами фінансової системи (системні загрози).

Незважаючи на джерела виникнення економічних загроз, вони прямо чи опосередковано впливають на фінансовий стан учасників банківської системи. Після реалізації цих загроз виникає низка операційних, кредитних ризиків або ризиків ліквідності, які $€$ основними причинами фінансових утрат i, як наслідок, зменшення власного капіталу банку. Проте варто зазначити, що наслідки кризи не обмежуються джерелами (суб'єктами) їх виникнення: потенційний ризик фінансового «зараження» інших фінансових інститутів може спровокувати в усій банківській системі «ефект доміно», який здатний вплинути на діяльність інших банків, що не відреагували на перші стрес-фактори. 3 іншого боку, криза банківської сфери, а саме криза ліквідності та відтоки пасивів, може бути причиною скорочення кредитної і інвестиційної діяльності банків, що, своєю чергою, спричинить недоотримання капіталу іншими економічними суб'єктами, і криза буде імпортована $з$ фінансового сектору у реальний сектор економіки. Усі ці нюанси мають бути враховані під час розроблення адекватної стрес-моделі банків.

Для виявлення ланцюгових ризиків, які можуть спровокувати кризу в усій банківській системі, центральні банки проводять макроекономічне стрестестування. Основним завданням макроекономічного стрес-тестування $€$ визначення найбільш імовірних загроз та їх сукупного впливу на банківську сферу.

Національний банк України запровадив щорічну оцінку стійкості банків за рахунок їх стрес-тестування на макрорівні. Оцінка здійснюється кожного року станом на 1 січня починаючи 31 січня 2018 р. і складається 3 трьох етапів (рис. 3).

Перший та другий етапи оцінки проходять усі платоспроможні банки. Перелік банків для III етапу визначає НБУ. Перелік складається 3 урахуванням впливу кожного банку на стабільність банківської системи.

Перший етап оцінки здійснюють незалежні аудиторські фірми в межах проведення щорічної аудиторської перевірки річної фінансової звітності, консолідованої фінансової звітності та іншої інформації щодо фінансово-господарської діяльності банку. Другий та третій етапи оцінки стійкості, під час яких здійснюється екстраполяція результатів першого етапу та стрес-тестування, проводить Національний банк України.

Стрес-тестування проводиться за базовим та несприятливим макроекономічними сценаріями із

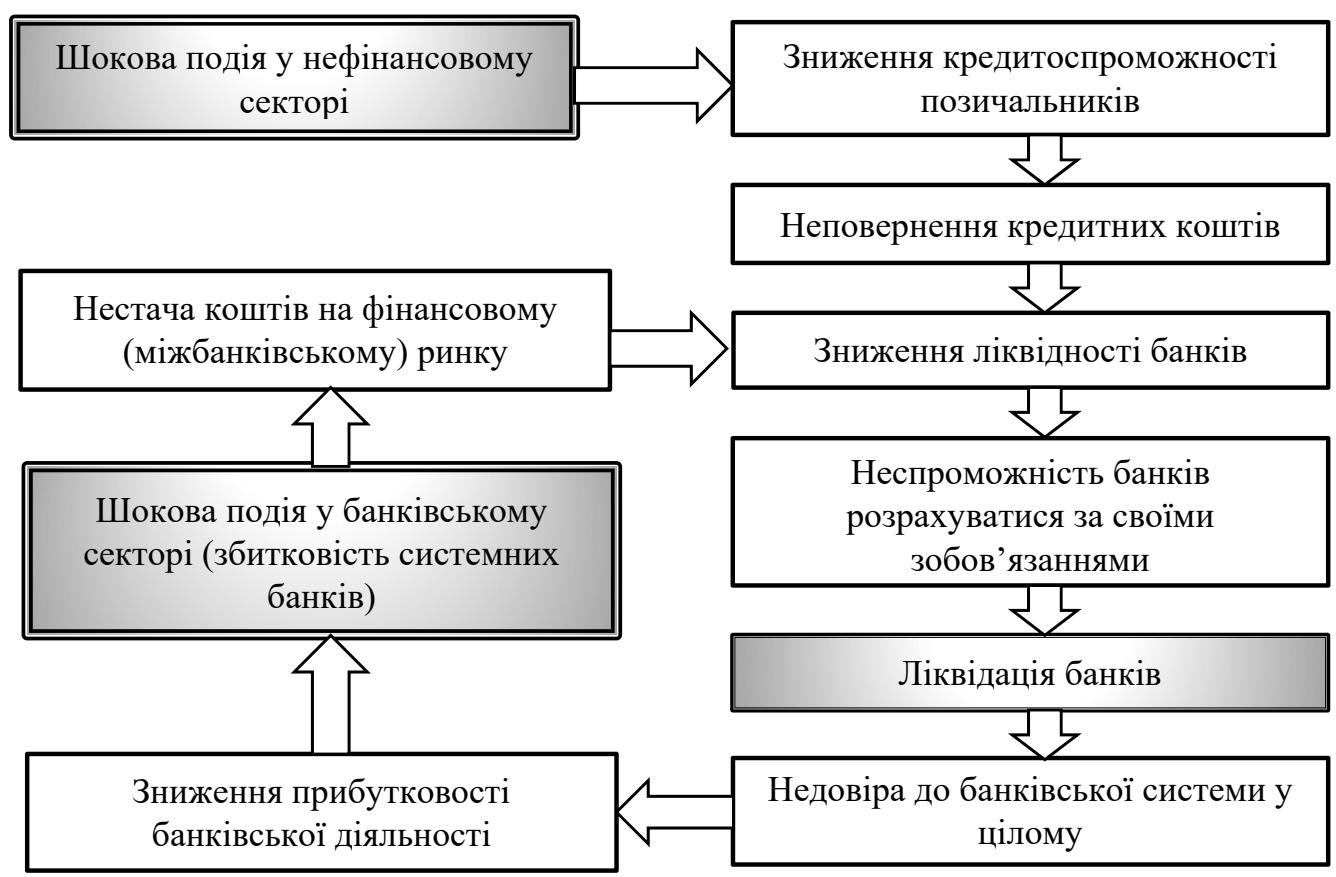

Рисунок 2 - Блок-схема впливу стрес-факторів на фінансовий сектор 


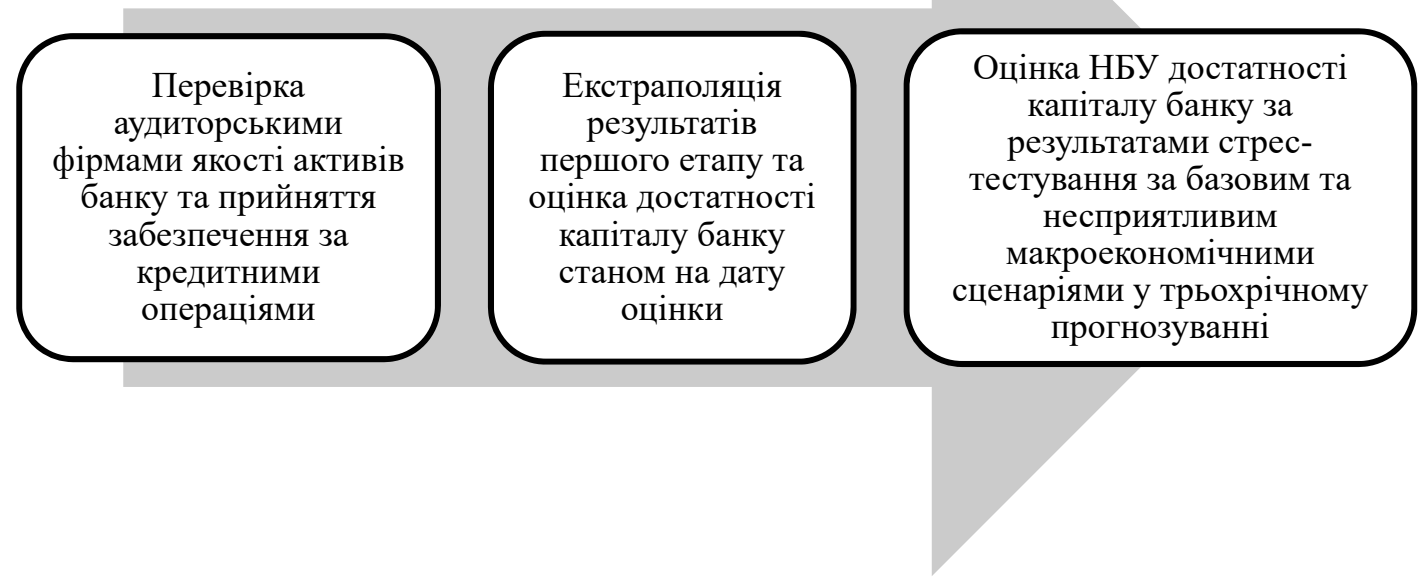

Рисунок 3 - Порядок здійснення стрес-тестування національним банком банківської системи України

Джерело: складено автором за даними [6]

застосуванням розроблених регулятором моделей. Національний банк щорічно актуалізує макроекономічні сценарії, моделі стрес-тестування та порядок їх використання. У разі якщо у банку за підсумками другого або третього етапу оцінки стійкості значення показників достатності капіталу нижче, ніж встановлено вимогами НБУ, у нього виникає потреба в докапіталізації. Банки, щодо яких виявлено потребу в капіталі, повинні розробити програму капіталізації та план заходів для підтримки або відновлення рівня капіталу. Запровадження такого інструменту, як щорічна оцінка стійкості, дає змогу виявити не лише поточні, а й майбутні ризики банків. Сьогодні діє саме така модель визначення стабільності банківської системи «зверху вниз» застосовується в Україні.

У 2019 р. НБУ провів стрес-тестування найбільших банків України (у тому числі ПАТ «Державний ощадний банк України»). Стрес-тестування проходили 29 банків, які загалом становлять понад 90\% активів банківської системи.

3 огляду на методику стрес-тестування, використану в 2019 р., НБУ було отримано такі результати щодо прогнозних показників складників основного капіталу (далі - ОК) державних банків (рис. 4) [8, с. 3].

Як видно з рисунку, якщо був би реалізований негативний сценарій, то загальна сума основного капіталу банків $з$ державною часткою знизилася б із 29 млрд грн до 0,9 млрд грн. Найбільш негативними чинниками у даному сценарії є зростання адміністративних витрат на 29 млрд грн і необхідність створювати резерви для великих боржників.

В аналізованому періоді погіршилися результати стрес-тестування двох державних банків: АТ «Державний ощадний банк України» та АТ «Укрексімбанк», передусім через амортизацію застави за старими непрацюючими кредитами. Додатково на ці банки негативно впливали низька поточна чиста процентна маржа та високе співвідношення операційних витрат i доходів (CIR).

За результатами стрес-тестування для банків установлювався необхідний рівень достатності основного та регулятивного капіталу. Він визначався, якщо розрахункові значення нормативів достатності капіталу фінансових установ хоча б в один із років прогнозного горизонту опускалися нижче граничних рівнів 7\% $\mathrm{i}$ $10 \%$ для базового та 3,5\% і 5\% - для несприятливого сценаріїв.

Розглянемо необхідний рівень нормативу достатності капіталу АТ «Державний ощадний банк України» за результатами стрес-тестування (рис. 5) [8, с. 2].

Як видно 3 рис. 5, розмір нормативу достатності основного капіталу АТ «Державний ощадний банк України» хоча й відповідає вимогам НБУ, однак під час реалізація негативного сценарію він має бути значно більшим, щоб забезпечити стійкість банку.

Інші показники діяльності банку за результатами стрес-тестування мають такий вигляд (табл. 1).

Як видно з результатів стрес-тестування, проведеного Національним банком України, навіть за базовим економічним сценарієм АТ «Державний ощадний банк України» у 2019 р. мав показати негативні результати. Основною проблемою банку є неробочі кредити, які в майбутньому мають вплинути на прибутковість банку (недоотримання доходу), ліквідність банку та загальну суму капіталу банку за рахунок їх переведення у LGD-кредити.

Якщо ж був би реалізований несприятливий макроекономічний сценарій, то банк узагалі міг стати неплатоспроможним, тому ним були вжиті необхідні заходи. У 2019 р. макроекономічні загрози за несприятливим сценарієм не відбулися, а за базовим сценарієм також банк спрацював із набагато ліпшими результатами, ніж показало стрес-тестування, тому результати стрес-тестування потрібно інтерпретувати обережно і 


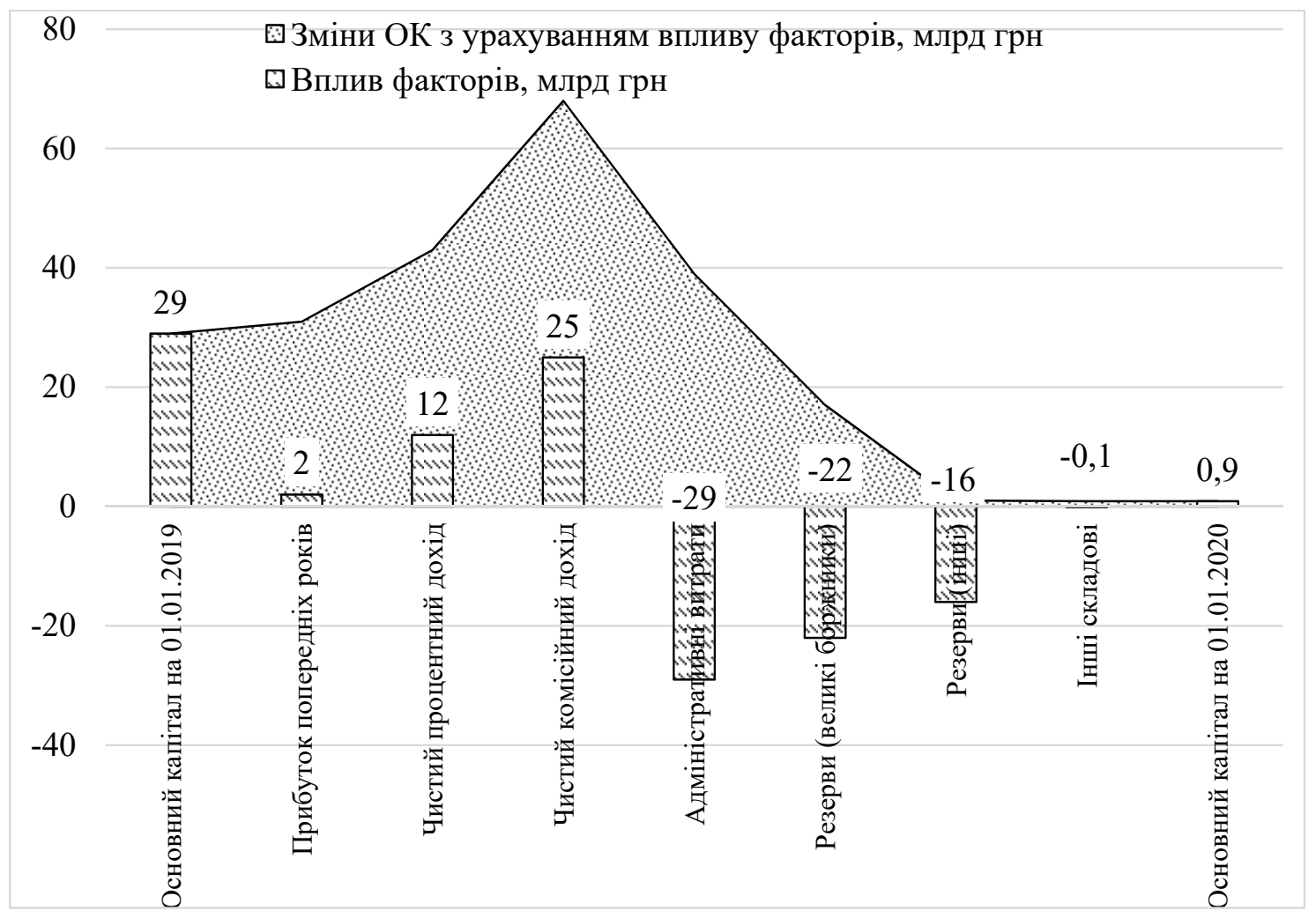

Рисунок 4 - Чинники зміни основного капіталу банків із державною часткою за несприятливим сценарісм у 2019 р.

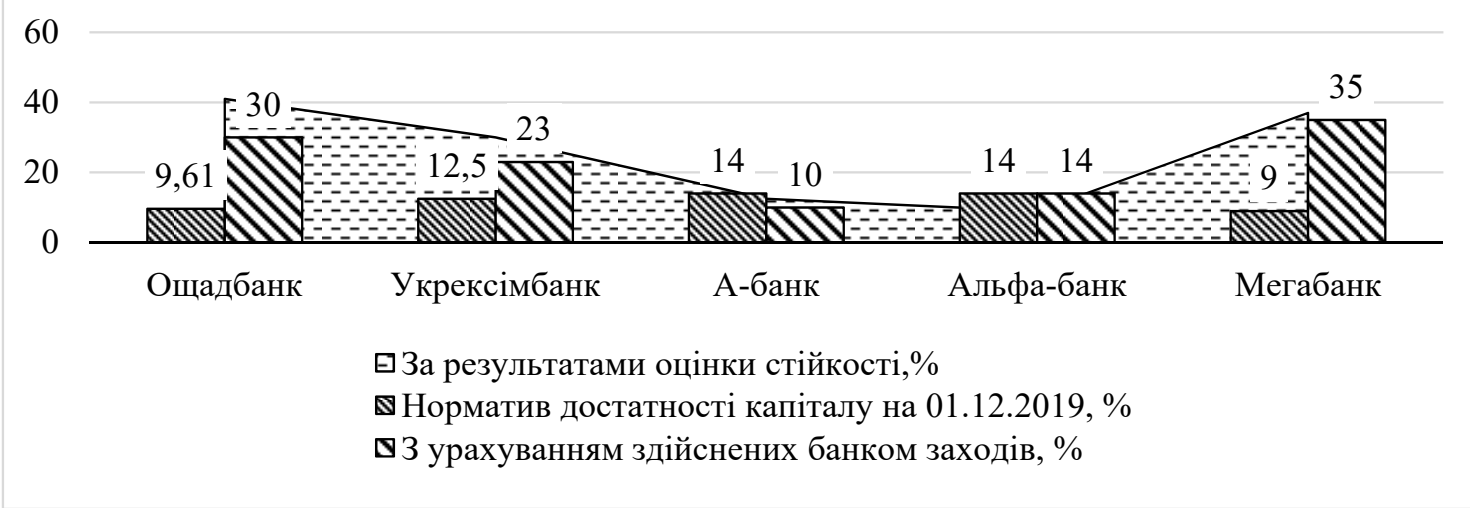

Рисунок 5 - Необхідні рівні нормативів достатності ОК банків, для яких виникла потреба в капіталі за результатами оцінки стійкості в 2019 р.

Таблиця 1 - Результати стрес-тестування АТ «Державний ощадний банк України», проведеного НБУ в 2019 р.

\begin{tabular}{|l|c|c|c|c|c|c|c|}
\hline \multirow{2}{*}{\multicolumn{1}{|c|}{ Показник }} & \multirow{2}{*}{$\begin{array}{c}\text { Дані на } \\
\text { 01.01.2019 }\end{array}$} & \multicolumn{2}{c|}{ За базовим макроекономічним } & \multicolumn{3}{c|}{$\begin{array}{c}\text { За несприятливим } \\
\text { макроекономічним сценарієм }\end{array}$} \\
\cline { 3 - 9 } & $\mathbf{2 0 1 9}$ рік & $\mathbf{2 0 2 0}$ рік & $\mathbf{2 0 2 1}$ рік & 2019 рік & $\mathbf{2 0 2 0}$ рік & $\mathbf{2 0 2 1}$ рік \\
\hline Основний капітал банку, млн грн & 8391 & 1085 & -2014 & -7414 & -10094 & -17118 & -25063 \\
\hline $\begin{array}{l}\text { Регулятивний капітал банку, } \\
\text { млн грн }\end{array}$ & 13201 & 2112 & -2071 & -7471 & -10151 & -17175 & -25120 \\
\hline $\begin{array}{l}\text { Норматив достатності основного } \\
\text { капіталу банку, \% }\end{array}$ & 9,38 & 1,23 & $-2,34$ & $-9,31$ & $-10,77$ & $-17,89$ & $-27,56$ \\
\hline $\begin{array}{l}\text { Норматив достатності } \\
\text { регулятивного банку, \% }\end{array}$ & 13,56 & 2,39 & $-2,41$ & $-9,39$ & $-10,83$ & $-17,95$ & $-27,62$ \\
\hline
\end{tabular}

Джерело: складено автором за даними [8, с. 4-7] 
Таблиця 2 - Розбіжності між реальними результатами діяльності АТ «Державний ощадний банк України» у 2018-2019 рр. і результатами стрес-тестування за базовим макроекономічним сценарієм ${ }^{1}$

\begin{tabular}{|l|l|l|}
\hline Показник & 2018 рік & 2019 рік \\
\hline Стрес-тестування ОК 2018-2019, млн грн & $12640^{2}$ & $1085^{3}$ \\
\hline Реальні дані ОК за результатами року, млн грн & 8391 & 9084 \\
\hline Різниця (реальні дані - стрес-тестування), млн грн & -4249 & +7999 \\
\hline Стрес-тестування регулятивнго капіталу (далі - РК) 2018-2019, млн грн & 164012 & 21123 \\
\hline Реальні дані РК за результатами року, млн грн & 13201 & 12355 \\
\hline Різниця (реальні дані - стрес-тестування), млн грн & -3200 & +10243 \\
\hline Норматив достатності основного капіталу за результатами стрес-тестування, \% & 16,92 & 1,233 \\
\hline Реальні дані нормативу основного капіталу, \% & 9,38 & 9,61 \\
\hline Різниця (реальні дані - стрес-тестування), в. п. & $-7,52$ & $+8,38$ \\
\hline Норматив достатності регулятивного капіталу за результатами стрес-тестування, \% & 222 & 2,393 \\
\hline Реальні дані нормативу регулятивного капіталу, \% & 13,56 & 13,13 \\
\hline Різниця (реальні дані - стрес-тестування), в. п. & $-8,44$ & $+10,74$ \\
\hline
\end{tabular}

Примітки: ${ }^{1}$ складено автором за даними джерел $[3 ; 7 ; 8]$

2 дані стрес-тестування банків України 2018 р.

3 дані стрес-тестування банків України 2019 р.

виключно в контексті ключових припущень, які лягли в основу моделі (табл. 2).

Із табл. 2 видно, що стрес-тестування не є точним прогнозуванням діяльності банків, воно тільки показує основні тенденції розвитку діяльності з урахуванням існуючих загроз. Так, результати стрес-тестування ПАТ «Державний ощадний банк України» були набагато оптимістичніші, ніж отримані реальні дані. Цьому $€$ декілька причин: стрес-тестування НБУ було проведено вперше і не були враховані всі загрози і тенденції макроекономічного розвитку. Зовнішній аудит і розрахунок ризиків діяльності банку був не досить якісним і показав більш оптимістичні прогнози. Під час проведення Національним банком України стрес-тестування 2019 р. ці недоліки були враховані, і результати стрестестування були набагато більш песимістичними, ніж результати реальної діяльності банку. Цьому сприяли як нереалізовані макроекономічні сценарії, так і врахування в діяльності банку попередніх результатів нагляду і більш успішне керування ризиками. Особливо це стосується кредитного ризику.
Висновки. Основною метою стрес-тестування $\epsilon$ виявлення «слабких місць» банківської системи у цілому й окремих «проблемних» банків зокрема. Із цим завданням макроекономічне стрес-тестування, яке здійснюється Національним банком України, 3 успіхом справляється. Завдяки стрес-тестуванню банки на першому етапі його здійснення проводять якісний внутрішній аудит і заздалегідь намагаються попередити проблеми 3 ліквідністю, на наступних етапах Національний банк перевіряє банки на стресостійкість, тим самим зміцнюючи стабільність банківської системи. 3 іншого боку, таке «перестрахування» банків зменшує їхню прибутковість. Так, у 2020 р. за рахунок такого макроекономічного шоку, як вимушений карантин через гостру респіраторну хворобу COVID-19, банки збільшили свої резерви під очікувані збитки у 2,5 рази, тим самим знизивши свою прибутковість на 20\% [4]. Однак у цілому по банківській системі був отриманий прибуток, а тому запобіжні заходи діють і дають свої позитивні результати.

Список використаних джерел:

1. Jones T., Hilbers P., Slack G. Stress Testing Financial Systems: What to Do When the Governor Calls. IMF Working Paper. 2004. № 04/127. 38 pgs.

2. Бездітко Ю.М. Оцінка ризику «залежного розвитку» від присутності іноземного капіталу в банківській системі України. Глобальні та наиіональні проблеми економіки. 2017. Вип. 16. С. 637-641.

3. Нормативи та складові розрахунку регулятивного капіталу станом на 01.01 .2019 і 01.01.2020. Акціонерне товариство «Державний ощчадний банк Украӥни». URL: https://www.oschadbank.ua/ua/about/monthly-report (дата звернення: 04.02.2021).

4. Прибутковість банків у 2020 році залишається нижчою, ніж 2019 року - результати 9 місяців. Національний банк України. URL: https://bank.gov.ua/ua/news/all/pributkovist-bankiv-u-2020-rotsi-zalishayetsya-nijchoyu-nij-2019-roku--rezultati-9misyatsiv (дата звернення: 08.02.2021).

5. Про схвалення Методичних рекомендацій щодо порядку проведення стрес-тестування в банках України : Постанова Правління Національного банку України від 06.08.2009 № 460. Дата оновлення: 06.08.2009. URL: https://zakon.rada.gov.ua/ laws/show/v0460500-09 (дата звернення: 31.01.2021).

6. Результати оцінки стійкості банків та банківської системи України у 2018 році. Національний банк України. URL: https://bank.gov.ua/files/ kmZjtvtNlGQdmUJ (дата звернення: 30.01.2021).

7. Стрес-тестування банків України у 2018 році. Національнийбанк України. URL: https://bank.gov.ua/files/kmZjtvtNlGQdmUJ (дата звернення: 31.01.2021).

8. Стрес-тестування банків України у 2019 році. Національний банк України. URL: https://bank.gov.ua/files/ oALUrXBwHLWrwmD (дата звернення: 31.01.2021). 


\section{References:}

1. Jones T., Hilbers P., Slack G. (2004) Stress Testing Financial Systems: What to Do When the Governor Calls. IMF Working Paper, no. 04/127, pp. 38.

2. Bezditko Yu.M. (2017) Otsinka ryzyku «zalezhnoho rozvytku» vid prysutnosti inozemnoho kapitalu v bankivskii systemi Ukrainy [Assessment of the risk of "dependent development" from the presence of foreign capital in the banking system of Ukraine]. Global and national economic problems, no. 16, pp. 637-641.

3. Joint Stock Company "State Savings Bank of Ukraine" (2020) Normatyvy ta skladovi rozrakhunku rehuliatyvnoho kapitalu stanom na 01.01.2019 r. i 01.01.2020 r. [Standards and components of the calculation of regulatory capital as of 01.01.2019 and 01.01.2020]. Available at: https://www.oschadbank.ua/ua/about/ monthly-report (accessed 4 February 2021).

4. National Bank of Ukraine (2020) Prybutkovist bankiv u 2020 rotsi zalyshaietsia nyzhchoiu, nizh 2019 roku - rezultaty 9 misiatsiv [The profitability of banks in 2020 remains lower than in 2019 - the results of 9 months]. Available at: https://bank.gov.ua/ua/news/all/ pributkovist-bankiv-u-2020-rotsi-zalishayetsya-nijchoyu-nij-2019-roku--rezultati-9-misyatsiv (accessed 8 February 2021).

5. National Bank of Ukraine (2009) Pro skhvalennia Metodychnykh rekomendatsii shchodo poriadku provedennia stres-testuvannia v bankakh Ukrainy: Postanova Pravlinnia Natsionalnoho banku Ukrainy vid 06.08.2009 r. № 460 [On approval of Methodical recommendations on the procedure for conducting stress testing in banks of Ukraine: Resolution of the Board of the National Bank of Ukraine of August 6, 2009, no. 460]. Available at: https://zakon.rada.gov.ua/laws/show/v0460500-09 (accessed 31 January 2021).

6. National Bank of Ukraine (2018) Rezultaty otsinky stiikosti bankiv ta bankivskoi systemy Ukrainy u 2018 rotsi [Results of the assessment of the stability of banks and the banking system of Ukraine in 2018]. Available at: https://bank.gov.ua/files/ kmZjtvtNlGQdmUJ (accessed 30 January 2021).

7. National Bank of Ukraine (2019) Stres-testuvannia bankiv Ukrainy u 2018 rotsi [Stress testing of Ukrainian banks in 2018]. Available at: https://bank.gov.ua/files/kmZjtvtNlGQdmUJ (accessed 31 January 2021).

8. National Bank of Ukraine (2020) Stres-testuvannia bankiv Ukrainy u 2019 rotsi [Stress testing of Ukrainian banks in 2019]. Available at: https://bank.gov.ua/files/oALUrXBwHLWrwmD (accessed 31 January 2021).

Posadnieva Oksana

Kherson National Technical University

\section{MACROECONOMIC STRESS TESTING OF BANKS AS A TOOL FOR ENSURING THE SUSTAINABILITY OF THE BANKING SYSTEM}

The article considers the need for macroeconomic stress testing. An efficient and reliable banking system of any state is the basis for the stability of the financial system as a whole. In the context of globalization of economic relations and internationalization of banks, the domestic banking system accepts challenges in terms of various risks both at the macroeconomic and global levels. At present, the financial turmoil of one country due to international banks and close economic ties resonates in the banking sector of another country. This is especially true of crises in the financial markets of economically developed countries, which have a significant impact on the financial markets of developing countries. Such countries continue to experience deeper economic shocks than the countries that were the source of the crisis. The last financial and economic crisis of 2008-2009 showed the vulnerability of the banking system to macroeconomic shocks. The introduction of mandatory stress testing has become a necessary condition for ensuring the stable functioning of national banking systems. For the National Bank of Ukraine, stress testing is a fairly new practice and therefore needs to be improved. Thus, the problem of finding an effective mechanism that would most accurately determine the impact of changes in macroeconomic indicators on banks' capital and their financial stability is particularly acute, so the issue of organizing stress testing of banks at the macroeconomic level is relevant. The study was conducted using systematic and comparative methods of analysis - to justify approaches to the implementation of stress testing at the macro and micro levels. Calculation-analytical and graphical methods were used in the processing of actual data. The study showed the impact of stressors from the real and financial sectors of the economy on the activities of individual banks and the banking system as a whole. The procedure of stress testing by the National Bank of Ukraine is given and all its stages are described. The paper also investigates the methodology of stress testing by the National Bank of Ukraine. There are two state-owned banks that have shown the worst results in stress testing. The results of stress testing of JSC «State Savings Bank of Ukraine» and the real results of its activities for similar periods are compared. Conclusions are made on the interpretation of stress test results at the macro level. The need for further stress testing to ensure stability in the banking sector has been proven.

Key words: banks, banking system, stress testing, macroeconomic risks, scenarios, sustainability.

JEL classification: E20, G21 